\title{
Bacterial Contamination Associated with Mobile Cell Phones among Undergraduate Students of Federal University of Lafia, Nasarawa State, Nigeria
}

\author{
${ }^{* 1,2}$ Y. Ya'aba, ${ }^{2}$ A. Chuku, 2 U. S. Okposhi, ${ }^{2}$ N. S. Hadi and ${ }^{2}$ S. A. Ramalan \\ ${ }^{1}$ Department of Microbiology and Biotechnology, National Institute for Pharmaceutical Research and Development (NIPRD) Abuja, \\ Nigeria \\ 2Department of Microbiology, Federal University of Lafia, Nasarawa State, Nigeria \\ [ ${ }^{*}$ Corresponding Author: E-mail: yakyabnig71@gmail.com]
}

\begin{abstract}
Mobile cell phones are extensively used globally. This study was aimed at determining bacterial contamination associated with mobile cell phones among undergraduate students of Federal University of Lafia, Nasarawa State, Nigeria. One hundred swab samples from mobile cell phones were randomly collected from the students' cell phones between August 2019 and December 2019. Demographic factors like age, gender, mobile phone type, storing of mobile cell phones, cleaning habits and use in toilets were collected using a semi-structured questionnaire. The samples were analysed using standard microbiological techniques. The data collected were analysed using percentile and SPSS version 20.0. The value $(p<0.01)$ was statistically considered to have significant associations. Microbial analysis showed that 70 nondisinfected samples were contaminated by eight diverse types of bacteria, which included Escherichia sp., Salmonella sp., Bacillus sp., Pseudomonas sp., Staphylococcus sp., Klebsiella sp., Micrococcus sp and Enterobacter sp. The swabbed cell phones of females (56.3\%) were more contaminated than those of males (43.7\%) with bacterial load count of $41.9 \times 10^{3}$ and $28.8 \times 10^{3} \mathrm{CFU} / \mathrm{mL}$ among females and males, respectively. The mobile cell phones used in toilets $(75.0 \%)$ were highly contaminated by bacteria. Users who did not cut their nails had higher contamination (69.4\%) than those users who cut their nails $(34.3 ; p=$ 0.01). The age of mobile cell phones within $6-12$ months had $55.5 \%$ for females and $23.5 \%$ for males. This study showed that mobile cell phones harbor bacteria liable for causing health threats to handlers. Therefore, awareness programs concerning hand hygiene and discouraging their use in toilets to avoid causing severe health consequences. The use of disinfectants to wipe mobile cell phones whenever contamination is encountered is advocated to safeguard public health.
\end{abstract}

Keywords: Mobile Cell Phone, Swabs, Microbes, Contamination

\section{INTRODUCTION}

The use of mobile cell phones has expanded rapidly on a global scale and has brought numerous changes in the daily lifestyles of individuals. In Nigeria, it is estimated in 2017 that $71 \%$ of the population use mobile cell phones as the main platform for communication and accessing the Internet (Gillwald et al., 2018). Pathogenic microbes can be widely spread through direct physical contact among individuals or through contaminated lifeless objects, and other surfaces especially at various user-crossing points in institutions or communities (Oluduro et al., 2011). Studies proved that many pathogenic bacteria can be found on fomites and other surfaces can survive for long periods depending on environmental factors such as temperature and relative air humidity (Grice et al., 2009).

Mobile cell phones are essential tools of communication, both at home, in school and at the workplace. They are always picked, dropped or pocketed, thus the possibility of acquiring and harboring microorganisms from the handlers and the environment. Mobile cell phones as lifeless objects have been revealed to support microbial survival on their surfaces. Microbes such as bacteria, viruses such as influenza and corona can persevere for a few days while herpes virus can persevere for a week (Abad et al., 1994; Kramer et al., 2006). Several studies have shown 
that cell phones contaminated with pathogenic bacteria play a big role in the spread of infectious disease (Brady et al., 2006; Tagoe et al., 2011). Many users do not generally know the microbial load on many regular objects within their living and workplaces (Al-Ghamdi et al., 2011; Shalinimol, 2016). The unclean ways of handling such objects make them a cardinal reservoir of an assembly of pathogenic microorganisms (Zakai et al., 2016; Adhikari et al., 2018) thus mobile cell phones surfaces might serve as fomites in the transmission of these microbes (Bhoonderowa et al., 2014).

Several studies carried out on mobile cell phones have exhibited the presence of some microbes such as Bacillus sp., Staphylococcus aureus, Enterococcus sp., Escherichia coli, Streptococcus sp., Proteus sp., Pseudomonas aeruginosa, Klebsiella sp., Acinetobacter and coliforms on medical personnel (Brady et al., 2006; Ramesh et al., 2008; Nwankwo et al., 2014), students and patients (Tekerekoğlu et al., 2011; Nwankwo et al., 2014).

Use and handling of mobile cell phones is common among students in tertiary institutions in Nigeria (Ozdalga et al., 2012; Robinson et al., 2013) and this increases the chances for crosscontamination amongst individuals (Ulger et al., 2015). At present, there are no guidelines for disinfection of mobile cell phones as an emphasis on disease control practices. This study was designed to determine the extent of bacterial contamination of mobile cell phone surfaces among undergraduate students of Federal University of Lafia, Nasarawa State, Nigeria.

\section{MATERIALS AND METHODS}

\section{Study Design and Area}

The study was carried out in the Faculty of Science, Federal University of Lafia (FUL), Nasarawa State, Nigeria from August 2019 to December 2019. Approval for the study was given by the Health Research and Ethics Committees (HREC) of Nasarawa State, Ministry of Health, Lafia in accordance with the code of ethics for biomedical research involving human subjects (NHREC/18/09/2019). Consent to participate was sought from volunteer students and were informed about the confidentiality of information that they provide in the questionnaire and rights to participate or refuse to participate in the study. Socio-demographic data such as age, gender and status of each student were extracted by a semi-structured questionnaire. Information regarding the type of mobile phones used, a span of use by the users, the practice of handling the mobile phones such as disinfection, place of storing (if not in use) and their use in toilets, kitchen or laboratory were also collected.

\section{Sample Collection and Processing}

A total of 70 mobile cell phones were swabbed out of which 34 belonged to male students. The hearing (speaker) and the back regions of the mobile cell phones were swabbed using sterile swab sticks. The swab samples were immediately placed in sterile airtight containers and transported to the laboratory. Another set of 30 mobile phones, 15 each from male and female volunteer students were cleaned with $70 \%$ ethanol to disinfect prior to swabbing and served as the control for the study. Microbiological examination of all samples collected was conducted. Briefly, swab sticks were dipped in $0.5 \mathrm{~mL}$ saline water and inoculated on the following culture media: Nutrient agar, MacConkey agar, Mannitol Salt Agar, Eosin Methylene Blue agar, Selenite Cysteine agar and Salmonella - Shigella agar. The culture plates were then incubated at $37^{\circ} \mathrm{C}$ for $48 \mathrm{hrs}$ (Forbes et al., 2007).

\section{Bacterial Count and Identification of Isolates} Immediately, after incubation, the plates were checked for bacterial growth and counted using a colony counter and expressed as colony-forming units per millilitres (CFU/mL). Isolates were identified by colony morphology, arrangement, size and color as described by Barry (2012). The isolates were further subjected to Gram staining reaction. The Gram-positive bacteria were further tested for oxidase, catalase, coagulase, oxidative/ fermentative tests, methyl red and Voges-Proskauer tests. Gram-negative bacteria 
were identified using colony morphology and the following biochemical tests: indole, methyl red, Voges Proskauer, citrate, triple sugar Iron, catalase, oxidase, urease, oxidative/fermentative tests ( Forbes et al., 2007).

\section{Statistical Analyses}

Descriptive statistics were used to present the socio-demographic information and bacterial count analysis. The results were presented in tabular form and analysed using percentile and SPSS version 20.0 .

\section{RESULTS}

Table 1 presents the demographic characteristic of participating students concerning cell phone bacterial contamination. The results suggest 72.2 $\%$ bacterial contamination amongst female students while $75.0 \%$ of phones used in toilets were observed to be contaminated. Mobile phones of users who do not cut their nails regularly were more contaminated with bacteria $(69.4 \%)$. Phones recently purchased by male students (6 -12 months) were less contaminated $(23.5 \%)$ when compared with female students within the same period (55.5\%). No cell growth was demonstrated for cell phones disinfected before swabbing.

Results presented in Table 2 identify eight bacterial isolates present as contaminants on cell phones of students selected for this study. The bacterial isolates were identified as Escherichia sp., Salmonella sp., Bacillus sp., Pseudomonas sp., Staphylococcus sp., Klebsiella sp., Micrococcus sp and Enterobacter sp.

The non-disinfected 70 mobile cell phones (34 from males and 36 from females) had revealed growth, out of which the highest proportion of mobile cell phones from females $(55.6 \%)$ than males (47.1\%). As presented in Table 3, $55.6 \%$ of cell phones belonging to female students were contaminated with Staphylococcus sp., Escherichia sp. (41.7\%), Klebsiella sp. (38.9\%), Enterobacter sp. (36.1\%), Pseudomonas sp. (25.0\%), Bacillus sp. (22.2\%), Salmonella sp. (19.4\%) and Micrococcus sp (11.1\%). Mobile cell phones belonging to male students were more contaminated with Staphylococcus sp., (47.1\%) and Escherichia sp. (38.2\%).

Table 1: Demographic characteristics of selected students in Federal University of Lafia associated with cell phone bacterial contamination

\begin{tabular}{|c|c|c|c|c|}
\hline \multirow{2}{*}{$\begin{array}{l}\text { CHARACTERS } \\
\text { (USERS) }\end{array}$} & \multicolumn{4}{|c|}{ DISTRIBUTION OF CONTAMINATED MOBILE CELL SAMPLES } \\
\hline & & $\begin{array}{c}\text { Male }(\%) \\
(n=34)\end{array}$ & $\begin{array}{l}\text { Female }(\%) \\
(n=36)\end{array}$ & $\begin{array}{l}\text { Total }(\%) \\
(\mathrm{n}=70)\end{array}$ \\
\hline Gender & $\begin{array}{l}\text { Male } \\
\text { Female }\end{array}$ & & & $\begin{array}{l}34(48.6) \\
36(51.4)\end{array}$ \\
\hline Mobile phone type & $\begin{array}{l}\text { Screen touch } \\
\text { Keypad }\end{array}$ & $\begin{array}{l}10(29.4) \\
24(70.6)\end{array}$ & $\begin{array}{l}10(27.8) \\
26(72.2)\end{array}$ & $\begin{array}{l}20(57.2) \\
48(68.5)\end{array}$ \\
\hline \multirow{2}{*}{$\begin{array}{l}\text { Use of mobile phones } \\
\text { in the toilet }\end{array}$} & Non users & $10(29.4)$ & $9(25.0)$ & $19(27.1)$ \\
\hline & Users & $24(70.6)$ & $27(75.0)$ & $51(72.9)$ \\
\hline \multirow{4}{*}{$\begin{array}{l}\text { Mobile phone storing } \\
\text { place } \\
\text { Users cutting nails }\end{array}$} & Pockets & $22(67.7)$ & $8(22.2)$ & $30(42.9)$ \\
\hline & Bags & $12(35.3)$ & $28(77.8)$ & 40 (57.1) \\
\hline & Nail cutters & $13(38.2)$ & $11(30.6)$ & $24(34.3)$ \\
\hline & Non nail cutters & $21(61.8)$ & $25(69.4)$ & $46(65.7)$ \\
\hline \multirow{3}{*}{$\begin{array}{l}\text { Time since } \\
\text { Possession and use } \\
\text { of mobile cell phone }\end{array}$} & Less than 6 month & $4(11.8)$ & $16(44.4)$ & $20(56.2)$ \\
\hline & $6-12$ month & $8(23.5)$ & $20(55.5)$ & $28(79.0)$ \\
\hline & $\begin{array}{l}\text { More than } \\
\text { 12month }\end{array}$ & $22(64.7)$ & - & $22(64.7)$ \\
\hline
\end{tabular}


Cumulative aerobic bacteria plate count showed $41.9 \times 10^{3} \mathrm{CFU} / \mathrm{mL}$ observed for mobile cell phones of female students while $28.8 \times 10^{3}$ $\mathrm{CFU} / \mathrm{mL}$ was recorded for mobile cell phones of male students (Table 4).

\section{DISCUSSION}

Hand contamination of various surfaces with pathogenic and non-pathogenic microbes has been documented (ICT, 2006). The isolation of enteropathogenic bacteria including Staphylococcus sp., Escherichia sp., Klebsiella sp., Enterobacter sp., Pseudomonas sp., Bacillus sp., Salmonella sp. and Micrococcus sp. from surfaces of the handheld mobile phones as demonstrated in this study is an indication of unhygienic practices, poor handling and sharing among multiple users (Yusha'u et al., 2010; Shahaby et al., 2012; Auhim, 2013; Bhoonderowa et al., 2014) and may predispose to opportunistic infections (Cerdá et al., 2006). Karabay et al. (2007) reported the isolation of $S$. aureus (8.1\%), Coagulase Negative Staphylococci (CONS) $(68.4 \%)$, E. coli $(26.0 \%)$,
Enterobacter faecalis (1.8\%) and Klebsiella sp. $(0.9 \%)$ from mobile phones swab samples. The aerobic bacterial plate count variation of $41.9 \times 10^{3}$ $\mathrm{CFU} / \mathrm{mL}$ recorded for female volunteer students supports strongly that mobile cell phones used by female students were contaminated by different species of bacteria (Table 3). Although not measured in this study, the likelihood to share mobile phones among peers could be more among female students. This and other social behaviours could be attributable to the cocktail of bacterial cells isolated from mobile cell phones of female students.

A report by the Infectious Disease Society of America (IDSA) in San Francisco disclosed that natural and artificial nails longer than 3 millimeters beyond the fingertip harbor more bacteria and yeast cells (Puleo, 2017). As shown in this study, surfaces of the mobile phone of users who kept long nails were highly contaminated $(69.4 \%)$ when compared with users who cut their nails $(30.6 \%)$

Table 2: Cultural, morphological and biochemical characterization of bacterial contaminants on cell phones of selected students in Federal University of Lafia

\begin{tabular}{|c|c|c|c|c|c|c|c|c|}
\hline $\begin{array}{l}\text { CHARACTERISTICS } \\
\text { Cultural }\end{array}$ & IS1 & IS 2 & IS3 & IS4 & IS5 & IS6 & IS7 & IS8 \\
\hline Shape & $\begin{array}{l}\text { Circ } \\
\text { ular }\end{array}$ & Circular & Irregular & Circular & Circular & Circular & Circular & Circular \\
\hline Elevation & $\begin{array}{l}\text { conv } \\
\text { ex }\end{array}$ & Convex & Flat & Low convex & convex & Convex & Convex & Convex \\
\hline Margin & $\begin{array}{l}\text { Entir } \\
\text { e }\end{array}$ & Entire & $\begin{array}{l}\text { Undulat } \\
\mathrm{e}\end{array}$ & Entire & Entire & Entire & Entire & Entire \\
\hline Wetness/Dryness & Wet & Wet & Dry & Wet & Wet & Wet & Wet & Wet \\
\hline Transparency & $\begin{array}{l}\text { Opa } \\
\text { que }\end{array}$ & Opaque & Opaque & Opaque & Opaque & Opaque & Opaque & Opaque \\
\hline Colour & $\begin{array}{l}\text { Cre } \\
\text { am }\end{array}$ & Yellow & Cream & Cream & Yellow & Cream & Yellow & Yellow \\
\hline Size & $\begin{array}{l}\text { Sma } \\
\|\end{array}$ & Small & Large & Medium & Medium & Medium & Medium & Small \\
\hline \multicolumn{9}{|l|}{ Morphological } \\
\hline Gram Staining & - & + & + & - & $e^{2}$ & - & + & - \\
\hline $\begin{array}{l}\text { Cell Type } \\
\text { Cell Arrangement }\end{array}$ & $\begin{array}{l}\text { Rod } \\
\text { Sing } \\
\text { le }\end{array}$ & $\begin{array}{l}\text { Cocci } \\
\text { Cluster }\end{array}$ & $\begin{array}{l}\text { Rod } \\
\text { Chain }\end{array}$ & $\begin{array}{l}\text { Rod } \\
\text { Single }\end{array}$ & $\begin{array}{l}\text { Rod } \\
\text { Single }\end{array}$ & $\begin{array}{l}\text { Rod } \\
\text { Single }\end{array}$ & $\begin{array}{l}\text { Cocci } \\
\text { Single }\end{array}$ & $\begin{array}{l}\text { Rod } \\
\text { Chain }\end{array}$ \\
\hline \multicolumn{9}{|l|}{ Biochemical } \\
\hline Catalase & + & + & + & + & - & + & + & + \\
\hline Coagulase & - & - & - & - & - & - & - & - \\
\hline Oxidase & - & - & - & - & - & - & - & + \\
\hline
\end{tabular}


Nigerian Journal of Basic and Applied Science (December, 2020), 28(2): 36-42

\begin{tabular}{lllllllll}
\hline Urease & - & - & - & + & + & + & - & - \\
$\begin{array}{l}\text { Indole } \\
\text { Citrate } \\
\text { Sugar }\end{array}$ & + & - & - & - & - & - & - & - \\
Glucose & $\mathrm{AG}$ & $\mathrm{A}$ & $\mathrm{A}$ & $\mathrm{A}$ & $\mathrm{A}$ & $\mathrm{AG}$ & $\mathrm{A}$ & $\mathrm{A}$ \\
Lactose & + & + & - & - & - & + & - & + \\
Possible Isolates & $\begin{array}{l}\text { Esc } \\
\text { Staphyl- }\end{array}$ & $\begin{array}{l}\text { Bacillus } \\
\text { heri- }\end{array}$ & $\begin{array}{l}\text { Pseudomon } \\
\text { ococcus }\end{array}$ & sp. & salmonell & Klebisella & Micrococc- & Enterobac \\
& chia & sp. & & & a sp. & sp. & us sp. & -ter sp. \\
& sp. & & & & & & & \\
\hline
\end{tabular}

Key: + = Positive, - = Negative, A = Acid, AG =Acid and Gas, sp. = species, IS = Isolate Number 1, 2, 3, 4, 5, 6, 7, 8

Table 3: Frequency of bacterial $s p$ isolated from mobile cell phones of selected students of Federal University of Lafia

\begin{tabular}{|c|c|c|}
\hline ISOLATES & $\begin{array}{l}\text { MALE STUDENTS' MOBILE CELL } \\
\text { PHONE }(n=34)\end{array}$ & $\begin{array}{l}\text { FEMALE STUDENTS' MOBILE } \\
\text { CELL PHONE }(n=36)\end{array}$ \\
\hline Escherichia sp. & $13(38.2)$ & $15(41.7)$ \\
\hline Staphylococcus sp. & $16(47.1)$ & $20(55.6)$ \\
\hline Salmonella sp. & $5(14.7)$ & $7(19.4)$ \\
\hline Enterobacter sp. & $11(32.4)$ & $13(36.1)$ \\
\hline Klebisella sp. & $12(35.3)$ & $14(38.9)$ \\
\hline Pseudomonas sp. & $6(17.6)$ & $9(25.0)$ \\
\hline Bacillus sp. & $5(17.7)$ & $8(22.2)$ \\
\hline Micrococcus sp. & $2(5.9)$ & $4(11.1)$ \\
\hline Total $(160)$ & 70 (43.7) & $90(56.3)$ \\
\hline
\end{tabular}

Table 4: Bacterial cell count of isolates from swabbed mobile cell phones of students of Federal University of Lafia

\begin{tabular}{|c|c|c|}
\hline $\begin{array}{l}\text { BACTERIAL } \\
\text { SPECIES }\end{array}$ & $\begin{array}{l}\text { BACTERIAL COUNT } \\
\text { MALES MOBILE CELL } \\
\text { PHONE (X103 CFU/ML) }\end{array}$ & $\begin{array}{c}\text { BACTERIAL COUNT } \\
\text { FEMALES MOBILE CELL } \\
\text { PHONE (X103 CFU/ML) }\end{array}$ \\
\hline Total viable count & 9.1 & 17.6 \\
\hline Escherichia sp. & 5.3 & 6.5 \\
\hline Staphylococcus sp. & 3.6 & 4.9 \\
\hline Salmonella sp. & 2.3 & 2.7 \\
\hline Enterobacter sp. & 3.9 & 4.4 \\
\hline Klebisella sp. & 2.1 & 2.3 \\
\hline Pseudomonas sp. & 1.1 & 1.6 \\
\hline Bacillus sp. & 0.9 & 1.1 \\
\hline Micrococcus sp. & 0.5 & 0.8 \\
\hline Total & 28.8 & 41.9 \\
\hline
\end{tabular}

Key: $\mathrm{CFU}=$ colony-forming unit

A similar study on college students conducted in Nepal indicated $56 \%$ bacterial contamination of mobile phones which included multidrug-resistant $S$. aureus (MRSA) and the use of mobile phones in toilets predisposes to multiple bacterial cell contamination of cell phone surfaces (Adhikari et al. 2018). Regular cleaning of mobile cell phones surfaces with disinfectant could prevent or reduce a load of microbial contamination of surfaces of mobile cell phones (Ramesh et al., 2008). 


\section{CONCLUSION}

Surfaces of handheld mobile phones of selected male and female students of the Federal University of Lafia were observed to be contaminated with different species of bacteria including Staphylococcus, Escherichia, Klebsiella, Enterobacter, Pseudomonas, Bacillus, Salmonella and Micrococcus species. Mobile cell phone surface of female students was found to be more predisposed to contamination in relation to personal hygienic practices. Hand hygiene, consistent disinfection of mobile cell phones, discouraging mobile phone use in toilets are some practices that should be encouraged especially amongst the youth.

\section{ACKNOWLEDGEMENT}

We are sincerely grateful to the management, lecturers and technologists of the Department of Microbiology, Federal University of Lafia.

\section{REFERENCES}

Abad, F. X., Pinto, R. M., \& Bosch, A. (1994). Survival of Enteric virus on environmental fomites. Applied Environmental Microbiology, 60(10): 3704-3710.

Adhikari, S., Khadka, S., Sapkota, S., \& Shrestha, P. (2018). Methicillin resistant Staphylococcus aureus associated with mobile phones. SOJ Microbiology of Infectious Disease, 6(1):1-6.

Al-Ghamdi, A. K., Abdelmalek, S. M. A. and Ashshi, A. M. (2011). Bacterial Contamination of Computer Keyboards and Mice, Elevator Buttons and Shopping Carts. African Journal of Microbiology Research, 5(23):39984003.

Auhim, H. S. (2013). Bacterial contamination of personal mobile phones in Iraq. Journal of Chemistry, Biology and Physical Science, 3(4):2652-2656.

Brady R. R. W., Verran, J., Damani, N. N., \& Gibb, A. P. (2009). Review of mobile communication devices as potential reservoirs of nosocomial pathogens. Journal of Hospital Infection, 71: 295300.

Barry, C. (2012). Laboratory Application in Microbiology: A case study Approach, $2^{\text {nd }}$ ed., New York: McGraw-Hill.

Bhoonderowa, A., Gookool, S., \& BiranjiaHurdoyal, S. D. (2014). The Importance of Mobile Phones in the Possible Transmission of Bacterial Infections in the Community. Journal of Community Health, 39(5):965967.

Cerdá, B., Soto, C., Albaladejo, M. D., Martínez, P., Sánchez-Gascón, F., TomásBarberán, F., \& Espín, J. C. (2006). Pomegranate juice supplementation in chronic obstructive pulmonary disease: a 5-week randomized, double-blind, placebo-controlled trial. European Journal of Clinical Nutrition, 60(2):24553.

Forbes, B., Sahm, D., \& Weissfeld, A. (2007). Bailey and Scott's diagnostic microbiology. 12th ed. London: Mosby, Inc. pp 1024.

Gillwald, A., Odufuwa, F., \& Mothobi, O. (2018). The state of ICT in Nigeria. Policy paper series (5): After access state of ICT in Nigeria. Retrieved from http://extensia$1 \mathrm{td} . \mathrm{com} / \mathrm{wp}$ content/uploads/2018/11/After-AccessNigeria-state-of-ICT-2017.pdf.

Grice, E. A., Korg, H. H., Conlan, S., Deming, CB., Daris, J., Young, D.C., \& Bouffard, G. G. (2009). Topographical and temporal diversity at the human skin microbes. Science, 324 (5931): 11901192.

Infection Control Today, (ICT). (2006). Fomites and infection transmission. Retrieved May 28, 2018. Available online at https://www.infectioncontroltoday.com/h and-hygiene/fomites-andinfectiontransmission.

Karabay, O., Koçoglu, E., \& Tahtaci, M. (2007). Short report the role of mobile phones in the spread of bacteria associated with 
nosocomial infections. Journal of Infection in Developing Countries, 1(1):72-73.

Kramer, A., Schwebine, I., \& Kampf, G. (2006). The length of pathogens survival on Inanimate objects. A systematic review. British Medical Council on Infections Disease, 6:130.

Nwankwo, E. O., Ekwunife, N., \& Mofolorunsho, K. C. (2014). Nosocomial pathogens associated with the mobile phones of healthcare workers in a hospital in Anyigba, Kogi state, Nigeria. Journal of Epidemiology and Global Health, 4(2):135-140.

Oluduro, A. O., Ubani, E. K. and Ofoezie, I. E. (2011). Bacterial assessment of electronic hardware user interfaces in lle-lfe, Nigeria. Revista de Ciencias. Farmaceuticas Basicas e Aplicada, 32(3):323-334.

Ozdalga, E. M. D., Ozdalga, A. B. S., \& Ahuia, N. M. D. (2012). The smart phone in medicine: A review of current and potential use among physicians and students. Journal of Medical Internet Research, 14(5): e128.

Puleo, R. M. (2017). Study links long fingernails and bacteria. Retrieved May 25, 2018. Available online at: http://abcnews.go.com/Health/story?id= 117161.

Ramesh, J., Carter, A. O., Campbell, M., H., Gibbons, N., Powlett, C., Moseley, H. Sr, Lewis D., \& Carter, T. (2008). Use of mobile phones by medical staff at Queen Elizabeth Hospital, Barbados: evidence for both benefit and harm. Journal of Hospital Infections, 70(2):160-165.

Robinson, T., Cronin, T., Ibrahim, H., Jinks, M., Molitor, T., \& Newman, J. (2013). Smart phone use and acceptability among clinical medical students: A questionnaire-based study. Journal of Medical Systems, 37:9936.
Shahaby, A. F., Awad, N. S., El-Tarras, A. E., \& Bahobial, A. S. (2012). Mobile phone as potential reservoirs of bacterial pathogens. African Journal of Biotechnology, 11(92):15896-15904.

Shalinimol, C. R. (2016). Identification and evaluation of Bacillus species bacteria from Sago Industrial Waste, DJ. International Journal of Advances in Microbiology and Microbiological Research, 1(1):1-6.

Tagoe, D. N., Gyande, V. K., \& Ansah, E. O. (2011). Bacterial Contamination of mobile phones- when your mobile phone could transmit more than just a call. Web Medical Central Microbiology, 2(10): 1-9.

Tekerekoğlu, M. S., Duman, Y., Serindağ, A., Cuğlan, S. S., Kaysadu, H., \& Tunc, E. (2011). Do mobile phones of patients, companions and visitors carry multidrug-resistant hospital pathogens? American Journal of Infection Control, 39(5):379-381.

Ulger, F., Dilek, A., Esen, S., Sunbul, M., \& Leblebicioglu, H. (2015). Are healthcare workers' phones a potential source of nosocomial infections? Review of the literature. Journal of Infection in Developing Countries, 9(10):1046-1053.

Yusha'u, M., Bello, M., \& Sule, H. (2010). Isolation of bacteria and fungi from personal and public cell phones: A case study of Bayero University, Kano (old campus). International Journal of Biomedical and Health Science, 6(1):97102.

Zakai, S., Mashat, A., Abumohssin, A., Samarkandi, A., Almaghrabi, B., Barradah, H., \& Jiman-Fatani, A. (2016). Bacterial contamination of cell phones of medical students at King Abdulaziz University, Jeddah, Saudi Arabia. Journal of Microscopy and Ultrastructure, 4(3):143-146. 